\title{
Introduction: Intersections of critical management research and practice: a multi-domain perspective
}

\author{
Maxim Voronov, Julie Wolfram Cox, \\ Tony LeTrent-Jones and David Weir
}

Scholars whose work has been broadly classified as falling within critical management studies (CMS) have sought to challenge the assumption that management is a neutral and value-free activity concerned with attaining the instrumental goals of organizations that serve a common good (Adler, Forbes and Willmott 2008). CMS is concerned with the 'questioning of taken-for-granteds, both about [management] practice and its social and institutional context ... Identifying and questioning both purposes, and conflicts of power and interest' (Reynolds 1998, p. 192). It aims to expose and reform the mundane and frequently unnoticed routines and practices that privilege some groups (and individuals) at the expense of others and create injustices in organizations and in the society at large (see Adler et al. 2008 for a more detailed overview of CMS foci).

CMS's critique targets not only managers and those who create and sustain the kinds of social arrangements that its proponents seek to expose and reform but also much of conventional management research and education. Critical researchers have pointed out that organizational science (including organizational behaviour, strategic management, human resources management, and so on) tends to take the managerial point of view (Alvesson and Willmott 1992b, Frost 1980) and to pay insufficient attention to the socioeconomic conditions within which organizations function (Nord 1974). The aim of such research often is to help managers attain their goals, such as overcoming resistance to change or attaining maximum productivity, more easily, but there often is a lack of mindfulness to the potentially detrimental impact of these prerogatives on other organizational stakeholders (Deetz 1992, 1995). The needs of employees are considered only from an instrumental perspective - if at all - and within a predetermined structure. Thus, it is argued that many 'conventional' organizational researchers tend to assume the universality of elite and managerial interests (Nord and Jermier 1992). 
Nonetheless, by tackling head-on the central issues in organizational life, such as power, politics, domination and identity formation, a CMS scholarship, far from offering a merely academic alternative, may accord more closely with the experience of managers and other practitioners.

In the decade and a half since the publication of Alvesson and Willmott's volume on the subject (1992a), CMS has gained increased prominence and influence in the academic community of organization studies and has made substantial impacts on the wider fields of strategy and management through the publication of several influential texts on CMS and the establishment of CMS conferences in the UK and the USA. Prominent among the more recent CMS texts are Studying Management Critically (Alvesson and Willmott 2003) and Critical Analysis of Organizations (Casey 2002). Until now, areas of most interest within the field have concerned its development as, at least in part, an extension of critical theory to management studies (for example, Alvesson and Willmott 1992a, 1996, 2003; Carr 2000), its (somewhat unlikely) inclusion of post-structuralist perspectives (Fournier and Grey 2000; see further, Alvesson and Deetz 1996), and its implications for reconsidering both the assumptions and practices of management sub-disciplines such as human resource management, marketing and strategy (Alvesson and Willmott 1996, 2003), management pedagogy (Cunliffe, Forray and Knights 2002; Dehler, Welsh and Lewis 2001; French and Grey 1996; Frost 1997; Prasad and Caproni 1997), management consulting (Clark and Fincham 2002) and sustainable development (Kearins and Springett 2003; Springett 2003).

The fifth biennial CMS conference was held in 2007 at Manchester in the UK (CMS5), attracting several hundred delegates. In the USA, CMS has moved from the status of a pre-conference workshop at the prestigious Academy of Management Annual Meeting to that of an interest group with a rapidly increasing international membership, and became a division at the August 2008 meeting. Such institutionalization has been met with mixed reactions from those who see CMS as an oppositional, if rather disparate, constellation of interests that cluster around an anti-performative stance, and a commitment to denaturalization and reflexivity (Fournier and Grey 2000), reflecting concerns about the nature of current critical management scholarship in relation to both mainstream management research and practice.

\section{CMS AND ITS RELATION TO PRACTICE}

Recently, the broader management and organization studies community has seen a great deal of debate about the relative importance of producing 
relevant and actionable knowledge and about the best ways to produce such knowledge (for example, McKelvey 2006; Starkey and Madan 2001; Van de Ven and Johnson 2006). Although this debate is not new (for example, Simon 1976), it appears to have intensified and brought about a questioning of the very notion of research process (for example, Mohrman, Gibson and Mohrman 2001; Van de Ven and Johnson 2006) and of the fundamental purpose of business schools and of business research (for example, Pfeffer and Fong 2002; Starkey and Madan 2001).

Against this backdrop, CMS has been having its own debate on this issue, with a number of scholars speaking out in favour of greater emphasis on the relevance and application of CMS insights to the real world (for example, Alvesson and Willmott 1996; Voronov and Coleman 2003; Watson 2001) and others against it (see Fournier and Grey 2000; Parker 2002 for reviews). It is this nexus between critical management research and practice that was the subject of our conference stream at CMS4 in Cambridge, becoming the starting point for most of the chapters in this volume. These chapters offer a variety of perspectives on both the practice of critical research as well as on the relationship between critical research and organizational practice; with this introduction we aim to set the stage for the perspectives contained herein.

\section{VARIETIES OF CMS PRACTICE}

The first facet of the notion of 'practice' parallels the increased preoccupation with actionable knowledge creation and practical relevance of management research that have become increasingly prominent features of the management research community. It reflects the growing influence of practitioner-led scholarship; this is seen in journals such as Reflective Practice and Action Research, advocacy by prominent scholars for an enhanced relationship between theory and practice in management research (e.g., Mohrman et al. 2001; Starkey and Madan 2001; Van de Ven and Johnson 2006), and at the Academy of Management conference, which headlines eminent practitioners as 'Distinguished Executive Speakers'. In other words, management researchers find themselves increasingly preoccupied with the examination of the extent to which their research is making a difference in the real world (for example, Pfeffer and Fong 2002) and try to find ways to reconnect with the interests and demands of the practitioners.

The other facet of 'practice' in management research is reflected in the 'practice turn' in social theory, as exemplified by the increased prominence of the work of Bourdieu, de Certeau, Foucault and Giddens, among others. The practice perspective has infiltrated a variety of sub-disciplines 
of management and organization studies, including strategic management (for example, Jarzabkowski 2003; Whittington 2003), technology (for example, Orlikowski 2000), new product development (for example, Dougherty 2001, 2004), organizational learning (for example, Contu and Willmott 2003; Gherardi 2006; Yanow 2000), and institutional change (for example, Seo and Creed 2002; Maguire, Hardy and Lawrence 2004).

The practice turn is characterized by the following three themes. First, it is concerned with grasping the link between broader societal structures and the 'shared understandings, cultural rules, language and procedures' (Whittington 2006, p. 614) that guide and shape human behaviour. Second, this perspective attends not only to what activities people undertake but also to how they undertake those activities. It attends to the minutiae of the everyday life of people and groups, through which such phenomena as new product development or strategy are accomplished. Third, the practice perspective construes individuals neither as deterministically manipulated by their institutional and societal context nor as free and autonomous agents, but as actors who artfully interpret and seek actively to navigate that context.

Chia and Holt (2006) use Heidegger's distinction of building versus dwelling mode to capture the difference between traditional and practice theorizing. They argue that in traditional research or in building mode researchers emphasize purposeful action by social actors. Actors (including researchers) are distinctly separate from the world and must first construct a mental representation of the world before being able to act on it. The key premise of the building mode is that 'individuals pre-exist their engagement with the world and that worlds pre-exist before they are lived in' (Chia 2004, p. 31). As we argue below, and as noted by a number of contributors to this volume, although CMS researchers have broken with the building mode as far as the relationship between the research subjects and the world is concerned, when it comes to our relationship to the research subjects we have tended to remain in this mode.

In contrast, in the dwelling mode, social actors "engage in iterative "wayfinding" by creating pathways that radiate outwards from their concrete existential situations' (Chia 2004, p. 31). People improvise their way through a world that is also in a constant state of flux. The actors' identities and the world are jointly and simultaneously co-created. This dwelling mode corresponds to the practice perspective on knowledge creation. From the practice perspective the focus shifts from knowledge as a noun to knowing as a verb. According to Blackler (1995, p. 1039):

Recast in this way, knowing in all its forms is analyzed as a phenomenon which is: (a) manifest in systems of language, technology, collaboration and control 
(i.e., it is mediated); (b) located in time and space and specific to particular contexts (i.e., it is situated); (c) constructed and constantly developing (i.e., it is provisional); and (d) purposive and object oriented (i.e., it is pragmatic).

Turned 180 degrees on to management research itself, the practice angle requires researchers to examine how research is done. What are the everyday minutiae by which researchers get their work done (see SamraFredericks 2003)? What are the institutional pressures to produce certain kinds of research, to choose particular kinds of methods, to address particular audiences and to choose particular journals or make other choices for dissemination of research findings? How do researchers artfully navigate that context on a day-to-day basis? Yet, Bourdieu's accusation (1992) that sociologists fail to use their own theories to reflect critically on themselves is equally applicable to CMS, and a serious reflection on the practice of critical research and the relationship between CMS research and practice has been sparse. Given that CMS now appears to have reached a degree of maturity and has been institutionalized in academia, we argue that it is timely to engage in such a reflection.

\section{CMS AS A HETERONOMOUS FIELD}

We argue that the relationship between critical management research and the world of practice has not been an harmonious one. This may be partly due to the traditional academic conceptualization of research and practice as separate activities at best, and incompatible tasks at worst. Bourdieu's notion of a heteronomous field (Bourdieu and Wacquant 1992) is a useful notion in explaining CMS discomfort with practice. A heteronomous field is one that is dominated by another field and is lacking in autonomy, that is, it lacks the ability to define its own standards by which activities are to be evaluated, rewards are to be allocated and players are to be moved to more or less dominant positions in relation to one another. CMS can be classified as a heteronomous or dominated field because it fits firmly within the broader academia. Although its stated objectives differ from those of many other academic disciplines, CMS overwhelmingly complies with the norms of the academic field and judges itself and its participants by those norms. Below we discuss the specific manifestations of CMS heteronomy.

\section{Succumbing to the Constraints of the University}

It appears that the heteronomy of CMS is rooted in its position in the university. It is virtually inevitable for a field seeking to be accepted by 
the university to have to play by the university's rules. This involves the need for CMS academics to comply with the university requirements for tenure and promotion: that is, publishing in top-tier peer-reviewed journals, obtaining grants from recognized funding agencies, using course evaluations as the key metric for assessing the quality of one's teaching, and so on.

Of course, it is no secret that institutional pressures, such as the tenure system, assessment of universities' performance by the number of scholarly publications by the faculty and so on, create incentives to focus on research that is publishable in academic journals that, above all, value theory. Yet, if this phenomenon is a result of the nature of academia, this begs the question: is academia the right place for CMS? Should CMS be yet another academic field that produces theory, the majority of which makes little, if any, impact outside academia? Our concern about the current state of affairs in CMS's relationship to the world of practice is summed up by the following observation by Watson (1994):

Perhaps I can express this unease by asking whether we would not all be most unhappy if, say, music critics or theatre critics were to be seen only talking to each other or writing such esoteric articles that they were to achieve no dialogue with either performers or audiences (p. 213).

\section{Perpetuating the Traditional Research/Practice Split}

The above point helps to explain the difficulty that CMS has had reconciling research and practice, since that difficulty is rooted in the traditional empiricist split between knowledge generation and knowledge application. Although CMS has incorporated a variety of post-empiricist approaches, including some forms of feminism, critical realism, postmodernism and post-structuralism, these approaches appear to be used as little more than lenses for interpreting research data and are rarely turned to by CMS researchers to illuminate our own practices, that is, exactly how we choose to make decisions regarding what research streams to pursue, what to do with our findings, where to publish our work and so on.

Thus, although we are increasingly finding a variety of research approaches in our journals, we are not finding nearly as many approaches to being CMS researchers. Although the topics of research differ between CMS and 'traditional' or 'mainstream' researchers, the research practice does not differ very much. Like our 'mainstream' colleagues, we seek to conduct the kind of research that is likely to be published in top academic journals and see that publication as the ultimate destination of the research process.

Furthermore, we contend that like mainstream management and 
organizational researchers, CMS scholars have for the most part failed to treat practitioners' knowledge, interests and concerns as legitimate. The argument that a greater focus on relevance might stifle the intellectual diversity and purity of the research enterprise or turn researchers into consultants or corporate trainers and 'to leave no definable social role or function for such institutions' (Grey 2001, p. S31) is valid but also appears to serve as a convenient rationalization for avoiding meaningful engagement with practitioners. Instead of finding a common ground between concerns of researchers and practitioners and negotiating the differences in epistemologies, interests and agendas (for example, Van de Ven and Johnson 2006), it is easier for us to work in isolation in pursuit of purely academic challenges, with the questions of practical relevance being hastily inserted into the concluding paragraphs of our research papers.

But there is an even bigger problem here. CMS researchers have documented in study after study how the taken-for-granted institutional and organizational arrangements tend to privilege some groups at the expense of others. The occupational culture of CMS with its emphasis on research as an end in itself privileges academics at the expense of practitioners. A great many members of the CMS community are either practitioners or former practitioners. Non-academics or former practitioners tend to discover CMS because it offers useful lenses to make sense of the frequently painful experiences in today's organizations. Yet, at the same time, while purportedly welcoming everyone into our big tent, by focusing exclusively on academic research, we may have been relegating to second-class status those members of our community who do not aspire to publish in top-tier journals or do not see themselves primarily as researchers.

\section{EMBRACING PRACTICE AS A STEP TOWARD AUTONOMY}

We argue that a major step toward establishing CMS as an autonomous field - or toward emancipating itself from domination by the traditional academic field - is to embrace the practice turn in both senses described above. First, this means adapting a practice perspective on knowledge, highlighted above, which would break with the traditional academic conceptualization of knowledge. Second, and by extension, this would result in a greater attention to the 'real world' impact of CMS research.

Although we are not arguing for an abolition of research that results in publication of articles and books, we maintain that the traditional research 
enterprise is unable to respond to the demands of the practice perspective. It is, therefore, crucial for CMS researchers to embrace modes of research that are more attuned to the creation of practice-based knowing, such as action research, participatory research, collaborative inquiry and so on. If CMS is to develop as an autonomous field - unhindered by the currently dominant academic norms that privilege research for the sake of research - CMS researchers must focus on the practical relevance of our scholarship in its broadest sense.

\section{ABOUT THIS VOLUME}

In assembling this volume, we aimed to showcase a range of perspectives that bring CMS 'to life', mostly through lived accounts of the negotiation of tensions experienced in everyday practice across domains of consultancy, research, teaching, managing and beyond (see further, Adler, Forbes and Willmott 2008; Knights and Willmott 1999).

This is not quite a traditional academic text. It provides a mix of chapters that have a more scholarly feel as well as those that are less academic and seek to make sense of the author's own challenges involved in 'doing' CMS. As a result, this volume is rather 'raw', reflecting the nature of practice - it is inevitably messy and chaotic and even painful (Chia and Holt 2006). Many of the authors reflect on their own coping with CMS practice, with all the ambiguity and pain that such practice may involve. As editors, we wished to preserve this rawness because we see it as our intervention into the predominantly academic CMS discourse. Indeed, not everyone is comfortable with this approach. One reviewer (for a different publisher) expressed concerns about the mixture of theoretical and applied chapters, while another reviewer observed the relatively small number of contributions by recognizable scholars and the potential negative effect of this on the marketability of the volume. We take these as manifestations of how far CMS still has to go in liberating itself from the domination by the traditional academic field.

The volume is divided into the following three parts:

1. Critical management research in action: choice and constraint in the generation and translation of actionable knowledge.

2. Critical teaching and learning: responsiveness and responsibilities in contemporary management education.

3. Critical identities: the critical turn in everyday domains of practice

Below we provide a brief overview of each section. 


\section{Critical Management Research in Action: Choice and Constraint in the Generation and Translation of Actionable Knowledge}

The first part of the volume tackles the issue of actionable knowledge generation and the theoretical and practical issues that must be addressed in the process. The major issues that the contributors discuss are the need to satisfy the potentially competing agendas of the multiple stakeholders and the factors that facilitate and inhibit such research, as well as the transfer of theoretical and practical knowledge between different contexts.

Roan, Loudoun and Lafferty (Chapter 1) discuss their research in a psychiatric hospital and reflect on the challenges and contradictions involved in trying to gain the trust of the employees while also satisfying the managers who funded the research.

Styhre (Chapter 2) argues for the need for joint academic-practitioner research ventures to advance the practical relevance of research and seeks to debunk several arguments frequently deployed against such research collaborations.

Waring (Chapter 3), drawing on her action research project of information systems implementation, explores the relevance of the notion of emancipation in the context of systems practice.

Clarke (Chapter 4) discusses the constraints and motivations of engaging in critical research, including the methodological and practical issues. He also notes the interplay between those factors.

Fletcher, Bailyn and Blake Beard (Chapter 5) report on their action research programme informed by feminist poststructuralist epistemology. They reflect on both the theoretical and practical utility of this research lens.

Kerr and Fox (Chapter 6) describe the leadership development programme that sought to integrate both technical and critical components. They explore how policy is transferred from one group to another and how the criticality can be maintained in the process.

\section{Critical Teaching and Learning: Responsiveness and Responsibilities in Contemporary Management Education}

The contributors to this part turn their attention to the inevitably messy and chaotic day-to-day practices by which teaching and learning are accomplished. They explore a variety of concerns that preoccupy both teachers and students of CMS, such as reconciling different paradigms in practice, aligning teaching and supervision methods with our beliefs, embodying the theories that we use to make sense of our world and so on.

Sloane (Chapter 7) discusses the potentially fruitful use of writings by 
such authors as Dreiser, Sinclair and Norris in management education. He argues that such books can be used to introduce a critical perspective into the classroom.

King (Chapter 8) seeks to reconceptualize Foucault from a theorist to an activist. Going beyond the use of Foucault as a theoretical lens, King examines how some of Foucault's work dissolved the theory-practice split and suggests that we, as CMS scholars, can do the same.

Priest and Hallebone (Chapter 9) turn to doctoral education in business and explore the ramifications of introducing a CMS lens into students' research originally framed within either positivist or interpretative traditions. They then consider whether or not the paradigms can be reconciled and offer some suggestions.

Macalpine and Marsh (Chapter 10) turn the analytical lens on themselves to investigate the process of research supervision of Masters theses driven by action research. The authors attempt to grasp the extent to which the rigour expected from the students is applicable to the analysis of the supervision as well as the extent to which the preoccupation with emancipation can be introduced into the research site.

Thanem and Wallenberg (Chapter 11) examine the potential clash between critical research and technical teaching and consider the ways that teaching can be brought into closer alignment with critical research tradition.

Grandy and Gibbon (Chapter 12) continue with the above theme by examining the introduction of CMS into a North American PhD programme in management with a special focus on possibilities and obstacles.

\section{Critical Identities: The Critical Turn in Everyday Domains of Practice}

The contributors to this section deal with everyday practice in a variety of domains: consulting, entrepreneurship and multinationals. The focus here is on the factors that shape and constrain individuals' identities, and how individuals attempt to rebel against and resist those constraints, exploring the extent to which people can find ways to create and carve out their own identities in the context of their daily work.

Harvey (Chapter 13) examines the practice of consulting "from the trenches" and explores whether or not critical consulting is possible. In other words, he investigates whether or not it is feasible to extend consulting beyond purely technical concerns into the realm of the critical.

Marsh (Chapter 14) also provides an 'in the trenches' account of consulting practice. She explores the extent to which consulting practice is gendered as well as the impact of this gendering on the consulting discourse and on the perceptions of consultants. 
Page (Chapter 15) continues with the exploration of gender in organizational life by reporting on an action research project designed to promote gender equity. She reflects on both the effectiveness of the intervention as well as on the potential and problematic of introducing CMS into organizational change interventions.

Benschop and Brouns (Chapter 16) take a critical look at the notion of the 'glass ceiling' and reflect on the kinds of practical and theoretical activities that it facilitates as well as hinders. They draw on research and consultancy projects to demonstrate the concept's limitations and offer more complex and multi-dimensional alternatives.

Johnson (Chapter 17) explores the possibility of infusing CMS insights into diversity training initiatives. She argues that as they are, diversity training interventions tend to perpetuate racial inequalities and status quo and suggests that CMS insights might make such interventions more meaningful in bringing about genuine change.

Latham, Jones and Betta (Chapter 18) bring insights from CMS in general and from discourse analysis in particular to the investigation of the entrepreneurship process. They examine several texts to expose differences in entrepreneurial discourses.

Crowley-Henry and Weir (Chapter 19) examine the career experiences of employees of a multinational company and note the conflict between the employees' attempts to retain international status while also seeking to carve out their individual career paths. The study connects to the discussion of power and control in international contexts.

\section{ACKNOWLEDGEMENT}

The editors would like to express their thanks to Georgina Caillard for her help preparing this manuscript.

\section{REFERENCES}

Adler, P.S., L.C. Forbes and H. Willmott (2008), 'Critical management', Academy of Management Annals, 1, 119-179.

Alvesson, M. and S. Deetz (1996), 'Critical theory and postmodernism approaches to organizational studies', in S. Clegg, C. Hardy and W.R. Nord (eds), Handbook of Organization Studies, London: Sage, pp. 191-217.

Alvesson, M. and H. Willmott (eds) (1992a), Critical Management Studies, London, UK: Sage.

Alvesson, M. and H. Willmott (1992b), 'On the idea of emancipation in management and organization studies', Academy of Management Review, 17(3), 432-464. 
Alvesson, M. and H. Willmott (1996), Making Sense of Management: A Critical Introduction, London, UK: Sage.

Alvesson, M. and H. Willmott (eds) (2003), Studying Management Critically, London, UK: Sage.

Blackler, F. (1995), 'Knowledge, knowledge work and organizations: an overview and interpretation', Organization Studies, 16(6), 1021-1046.

Bourdieu, P. (1992), 'Thinking about limits', Theory, Culture and Society, 9, 37-49.

Bourdieu, P. and L. Wacquant (1992), An Invitation to Reflexive Sociology, Cambridge: Polity Press.

Carr, A. (2000), 'Critical theory and the management of change in organizations', Journal of Organizational Change Management, 13(3), 208-220.

Casey, C. (2002), Critical Analysis of Organizations: Theory, Practice, Revitalization, London, UK: Sage.

Chia, R. (2004), 'Strategy-as-practice: reflections on the research agenda', European Management Review, 1(1), 29-34.

Chia, R. and R. Holt (2006), 'Strategy as practical coping: a Heideggerian perspective', Organization Studies, 27(5), 635-655.

Clark, T. and R. Fincham (2002), Critical Consulting: New Perspectives on the Management Advice Industry, Oxford: Blackwell.

Contu, A. and H. Willmott (2003), 'Re-embedding situatedness: the importance of power relations in learning theory', Organization Science, 14(3), 283-296.

Cunliffe, A., J.M. Forray and D. Knights (2002), 'Considering management education: insights from critical management studies', Journal of Management Education, 26(5), 489-495.

Deetz, S. (1992), Democracy in an Age of Corporate Colonization: Developments in Communication and Politics of Everyday Life, Albany, NY: SUNY.

Deetz, S. (1995), Transforming Communication, Transforming Business: Building Responsive and Responsible Workplaces, Cresskill, NJ: Hampton Press.

Dehler, G.E., M.A. Welsh and M.W. Lewis (2001), 'Critical pedagogy in the "new" paradigm', Management Learning, 32(4), 493-511.

Dougherty, D. (2001), 'Reimagining the differentiation and integration of work for sustained product innovation', Organization Science, 12(5), 612-631.

Dougherty, D. (2004), 'Organizing practice in services to capture knowledge for innovation', Strategic Organization, 2(1), 35-64.

Fournier, V. and C. Grey (2000), 'At the critical moment: conditions and prospects for critical management studies', Human Relations, 53(1), 7-32.

French, R. and C. Grey (eds) (1996), Rethinking Management Education, London: Sage.

Frost, P. (1980), 'Toward a radical framework for practicing organization science', Academy of Management Review, 5(4), 501-507.

Frost, P.J. (1997), 'Building bridges between critical theory and management education', Journal of Management Education, 21(3), 361-367.

Gherardi, S. (2006), Organizational Knowledge: The Texture of Workplace Learning, London: Sage.

Grey, C. (2001), 'Re-imagining relevance: a response to Starkey and Madan', British Journal of Management, 12(Special Issue), S27-S32.

Jarzabkowski, P. (2003), 'Strategic practices: an activity theory perspective on continuity and change', Journal of Management Studies, 40(1), 23-55.

Kearins, K. and D. Springett (2003), 'Educating for sustainability', Journal of Management Education, 27(2), 188-204. 
Knights, D. and H. Willmott (1999), Management Lives: Power and Identity in Work Organizations, London: Sage.

Maguire, S., C. Hardy and T.B. Lawrence (2004), 'Institutional entrepreneurship in emerging fields: HIV/AIDS treatment advocacy in Canada', Academy of Management Journal, 47(5), 657-679.

McKelvey, B. (2006), 'Response: Van De Ven and Johnson's "engaged scholarship": Nice try, but. .', Academy of Management Review, 31(4), 822-829.

Mohrman, S., C. Gibson and A. Mohrman (2001), 'Doing research that is useful to practice: a model and empirical exploration', Academy of Management Journal, 44(2), 357-375.

Nord, W.R. (1974), 'The failure of current applied behavioral science: a Marxian perspective', Journal of Applied Behavioral Science, 10, 557-578.

Nord, W.R. and J.M. Jermier (1992), 'Critical social science for managers? Promising and perverse possibilities', in M. Alvesson and H. Willmott (eds), Critical Management Studies, London, UK: Sage, pp. 202-222.

Orlikowski, W.J. (2000), 'Using technology and constituting structures: a practice lens for studying technology in organizations', Organization Science, 11(4), $404-428$.

Parker, M. (2002), Against Management, Cambridge, UK: Polity.

Pfeffer, J. and C.T. Fong (2002), 'The end of business schools? Less success than meets the eye', Academy of Management Learning and Education, 1(1), 78-95.

Prasad, P. and P.J. Caproni (1997), 'Critical theory in the management classroom: engaging power, ideology, and praxis', Journal of Management Education, 21(3), 284-291.

Reynolds, M. (1998), 'Reflection and critical reflection in management learning', Management Learning, 29(2), 183-200.

Samra-Fredericks, D. (2003), 'A proposal for developing a critical pedagogy in management from researching organizational members' everyday practice', Management Learning, 34(3), 291-312.

Seo, M. and W.E.D. Creed (2002), 'Institutional contradictions, praxis, and institutional change: a dialectical perspective', Academy of Management Review, 27(2), 222-247.

Simon, H.A. (1976), 'The business school: a problem in organizational design', in H.A. Simon (ed.), Administrative Behavior: A Study of Decision-Making Processes in Administrative Organization, New York: Free Press, pp. 1-16.

Springett, D. (2003), 'Business conceptions of sustainable development: a perspective from critical theory', Business Strategy and the Environment, 12(2), 71-86.

Starkey, K. and P. Madan (2001), 'Bridging the relevance gap: aligning stakeholders in the future of management research', British Journal of Management, 12(Special Issue), S3-S26.

Van de Ven, A.H. and P.E. Johnson (2006), 'Knowledge for theory and practice', Academy of Management Review, 31(4), 802-821.

Voronov, M. and P.T. Coleman (2003), 'Beyond the ivory towers: organizational power practices and a "practical" critical postmodernism', The Journal of Applied Behavioral Science, 39, 169-185.

Watson, T. (1994), 'Toward a managerially relevant but non-managerialist organization theory', in J. Hassard and M. Parker (eds), Toward a New Theory of Organizations, London, UK: Routledge, pp. 208-224.

Watson, T. (2001), 'Beyond managism: negotiated narratives and critical management education in practice', British Journal of Management, 12(4), 385-396. 
Whittington, R. (2003), 'The work of strategizing and organizing: for a practice perspective', Strategic Organization, 1(1), 117-126.

Whittington. R. (2006), 'Completing the practice turn in strategy research', Organization Studies, 17(5), 613-634.

Yanow, D. (2000), 'Seeing organizational learning: a cultural view', Organization, 7(2), 247-268. 